\title{
Ecological sensitivity of the Persian Gulf coastal region (Case study: Bushehr province)
}

\author{
${ }^{1}$ NOURI, J; ${ }^{2}$ DANEHKAR, A; ${ }^{3 *}$ SHARIFIPOUR, R \\ ${ }^{I}$ Department of Environmental Health Engineering, School of Public Health, Medical Sciences/ University of Tehran, \\ Tehran, Iran \\ ${ }^{2}$ Department of Fisheries and Environmental Sciences, Faculty of Natural Resources, University of Tehran Karadj, Iran \\ ${ }^{3}$ Department of Environmental Management, Graduate School of Environment and Energy, \\ Science and Research Campus, IAU, Tehran, Iran
}

\begin{abstract}
Coastal area sensitivity evaluation is in fact, the evaluation of an extraordinary ecological rich region. This study has been based on established criteria and values. The aim of this sensitivity evaluation has been to give objectivity to the Bushehr Province coastline region, so as to be able to pinpoint areas requiring ecological protection. With this objective, initially, the boundaries of the area under evaluation were first established, based on the findings of the Integrated Coastal Zone Management plan (ICZM). Then, based on these parameters and by geo-referencing photo mosaic Land Sat Satellite images (2003) and IRS' (2004) were taken and basic maps of two influential areas were evaluated within the above mentioned limits which included the coastal village boundaries. The coastal line of the area being evaluated (set back line) was $673.62 \mathrm{kms}$ comprising an area of 384,810 hectares. In this research the blueprint of a linear mathematical model was planned according to the Analytic Hierarchy Process method backed by the Arc-GIS Software program. In this model the value of influencing sensitivity factors were not applied in the same manner but by determining weight coefficients, the value and importance of each factor was determined according to the amount of sensitivity inflicted on the specified environment. In total, in the area under consideration, about 30 percent were defined as very high sensitivity areas. @.JASEM
\end{abstract}

Key words: Sensitivity evaluation, analytic hierarchy process method, geographical information system, coastal region, Persian Gulf,

\section{Introduction}

The coastal region can be defined as the meeting point of land and sea. Each one of these - land and sea - possesses a distinct and different eco-system, cohabiting side by side. The environment of the coastal region has developed naturally through the ages, and is one of the most complex and rich ecosystems found on earth. This region may be referred to as a "transfer and vulnerable area", since it is at this point, that pollution from the sea effects the ecological environment of the land, and vice versa. Thus, the polluting factors of one or the other - land and sea - can create potential threats to the entire ecosystem of that region. In marine ecological environment related literature, the term Sea Sensitive Area (S.S.A.) has been in use less than three decades. The importance of S.S.A. was first mentioned by the Marine Environment Protection Committee (1978). From 1986, the International marine Organization (I.M.O.) incorporated Program Recognition and Introduction of S.S.A. to its agenda. In 1991 this led to taking the decision to recognize regions which because of ecological, economical, social or scientific reasons, caused by international navigation activities, as "sensitive and vulnerable areas". Methods obtained from IMO's guidelines were adopted by the Organizing Committee's resolutions A-720 (17) and A-885 (21) and subsequently were approved and adopted officially by the General Assembly's resolution A-927 (22) in 1999. In its latest revision I.M.O. defines regions known previously as "Areas" now as "Sensitive Sea Areas (S.S.A.)".
IMO also mentions that the ecological environmental conditions of special sea areas are vulnerable to the activities of international navigation and as well existing protection factors related to the scope of activity of this organization are the reasons for determining Special Sea Sensitive Areas (IMO/MEPC, 2001).

The resolutions of the Rio Conference emphasized to the participating governments the immediate priority to identify and take positive action of the Sensitive Sea Area's ecosystems, specially coral reefs, creek and gulfs, tropical wetlands, Avicennia marine forests, sea bed plant life and aquatic fauna's spawning areas (I.U.C.N. 1992).

Sensitive Sea Areas that can be identified and selected in coastal internal waters, territorial waters, exclusive and economical zones, are regions which have sensitive coastal sources or that they are dependent on the sea.

Generally "sensitive areas" are known or defined as vital or critical regions thus stressing their extreme importance, as well as their natural vulnerability. The value of these areas should be recognized as independent or as supporting factors of other habitats or species. This point of view has been influenced by William Odom (1988), Grim Kalhor and Richard Chington's (1992) opinions about sensitive habitats. These types of habitats are capable of guaranteeing an ecological or social period and to perform a vital role in their survival (Majnoonian 2000).

Sensitive sea areas had been defined by a working group of the national sensitive sea area's protection 
program in 2001 and 2002 accordance with I.M.O.'s definition of potential and actual threats to the coastal regions:

"A sensitive Sea Area is the area of the coastal line which is vulnerable and in need of special protection due to ecological, social, economical, educational reasons and or scientific reasons in face of natural causes or human actions, especially marine navigational activities and requires special protective measures." (Danehkar, 2002).

In Iran the first actions taken to identify Sensitive Sea Areas started in 1994. However, at that time I.M.O. was just on the point of completing its studies of Sensitive Sea Areas, Iran continued to conduct its own research based on information that was known at that time, i.e., identification of those areas based on the prevention of extinction of mangrove jungles, coral reefs, spawning habitats of sea mammals and turtles, marine and aquatic birds hatching grounds, fish procreation beds, etc.

The standard methods to study or research "sensitive" or "vulnerable" areas and or to identify areas "under protection" are based on qualitative or quantitative criteria. Amongst these, we can point to IMO / MEPCs 2001 criteria in reference to Special Sensitive Sea Areas ; NOAA 2001 criteria of oil polluting of Sensitive Sea Areas; I.U.C.N's criteria to identify sea areas in need of protection (1999); criteria used to designate the list of regions and wetland areas registered by the Ramsar Convention (Davis, 1994); criteria for determining centers of habitat (Norse, 1993); evaluating factors of ecological power for determining of protective functions (Makhdoom, 2000); criteria to identify and determine natural and national causes (Majnoonian, 1991); the Ramsar Convention criteria for identification of important international wetlands (the $4^{\text {th }}$ Conference of the Ramsar Convention's member countries, 1990); regulations governing regions where hunting is forbidden (Majnoonian, 1990) ; criteria to choose important areas for birds (Evans, 1994 Grimmett, 1989); criteria to determine areas to be protected based on evaluation of habitats, living creatures and criteria of wetlands importance according to environmental changes (Kiaby\&Associates1987 / 2000); Salm and Clark criteria (Salm \& Clark, 1984) Salm and Price criteria (Salm \& Price, 1995) for selecting protected coast and sea areas ; criteria for selection of sensitive sea areas (Wait,1984) ; factors for determining reserved habitats' factors to determine area's boundaries (I.U.C.N., 1980); criteria of determining area's boundaries (I.U.C.N. / W.C.M.C., 1976 \& 86) and criteria for choosing national marina parks (Ray,1970). Needless to say, it is obvious, that criteria suggested by different global organizations can only be considered in a general manner and they cannot be considered as standards for all countries.

\section{MATERIALS AND METHODS}

The region under study in this research is the coastal area of the Province of Bushehr, situated in the South of Iran. It has a coastline of $744.49 \mathrm{kms}$ on the Northern part of the Persian Gulf. The area under evaluation in this study is based on the latest conclusions of the Integrated Coastal Zone Management (ICZM) plan of 2005.

Based on this study the coastal area includes some shoreline whose limits are determined by the extent of sea approach into land, referred to as the setback line.

The setback line is that part of the coast that becomes covered by seawater under stormy and windy conditions; therefore, it is unstable. Sandy hills and land vegetation can be found and can be identified on satellite images (ETM). The sea borders of the studied region were determined to coincide with water depths of 20 meters, while the outer limits of the coastal villages were determined to be the upper borders of the studied region.

Figuer 1, shows the boundaries of this study. These boundaries extend from the back-shore up to the coastal waters' limits and are approximately 3,848.10 square kms.

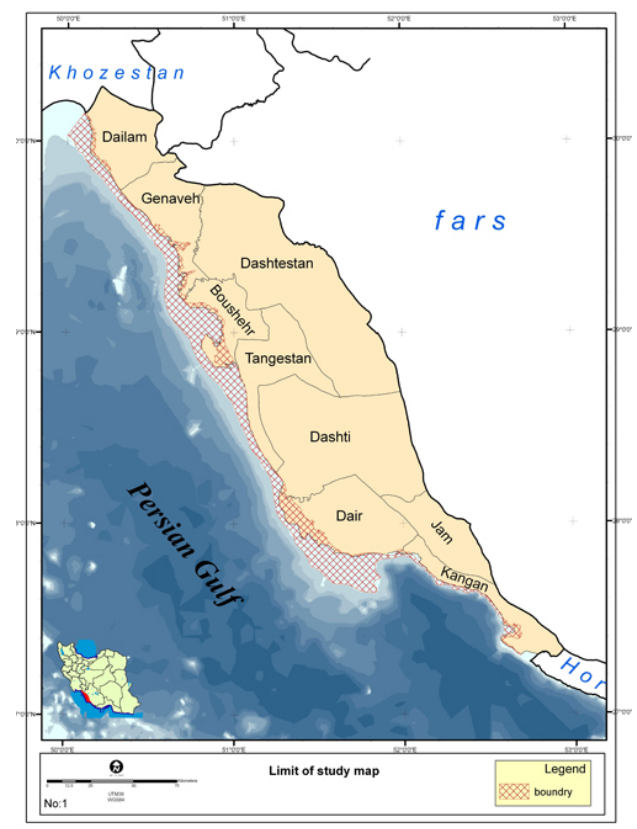

Fig. 1: Limited of the proposed sensitivity study

With use of satellite images (ETM) and (IRS) many ecological sources, land use maps and land forms of the area were recognized and surveyed and obtained data changed into digital figures, and together with the other descriptive data were shifted to ArcGIS software for the purpose of creation of data base In the case of blueprint a mathematical linear model to evaluate the area's sensitivity at first it was necessary to select the required investigating 
parameters so as to be able to evaluate the area's sensitivity in a scientific manner. Therefore by collecting parameters used in Iran and around the world and taking into consideration the special conditions of the region, and using the Delphi method - which is a recognized method of preparing opinion polls - questionnaires were prepared. Fill these questionnaires by Expertise to evaluation criteria and actual vulnerable criteria. These parameters had been identified in 50 different land control locations. Then based on the Analytical Hierarchy Process (AHP) and with the used of a revised EC software program, the priority and importance of the coefficients was calculated. It should be mentioned that, to avoid giving weight to personal opinions in the determined parameters, coefficients were prepared according to the AHP method and were presented to the experts familiar with the area under study and the value given to each main and secondary criteria, determined $1^{\text {st }}$ and $2^{\text {nd }}$ degree. All the criteria were down loaded in ArcGIS software program. This zoning was on the bases of distance evaluation method for point criteria and has been used as an extension of a straight line ArcGIS software program. Then according to the defined model a map was designed and was downloaded once for positive factors and once for negative factors. In confirmation the positive factor maps were deducted from the negative factor maps and finally maps that showed the area's sensitivity according to its vulnerability were obtained.

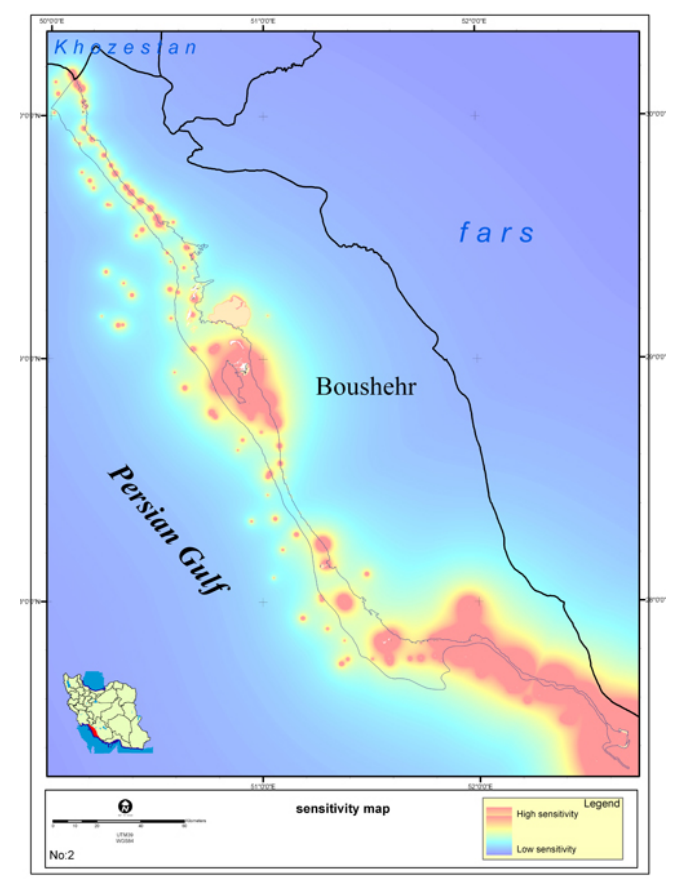

Fig. 2: Sensitivity map of the northern coastal area Boushehr Province

\section{RESULTS}

Based on the above described method, criteria for analyzing the area's sensitivity and protection coefficients were determined:

Table 1: Influence Parameters

- 7 Main Parameters

- $221^{\text {st }}$ degree Secondary Parameters

- $\quad 25 \quad 2^{\text {nd }}$ degree Secondary Parameters

Then by use of EC software program the priority and importance of the coefficients was calculated.

Based on the relative importance and priority determined for the safety coefficients of each parameter, a linear model of protection was obtained, with the aim of selecting protection centers in the regions under study according to the formula:

CMS: $\mathrm{K}(0.044 \mathrm{CU}+0.319 \mathrm{CH}+0.157 \mathrm{SA}+0.13$ $\mathrm{RA}+0.148 \mathrm{RP}+0.02 \mathrm{TO}+0.107 \mathrm{PR})$

Where:

CMS: Coastal sensitivity map

K : Fixed coefficient, 10000

$\mathrm{CU}$ : Coastal unevenness

$\mathrm{CH}$ : Coastal habitat

SA : Sensitivity animal

RA : Rare animal

RP : Rare plant

TO : Tourism

PR : Protected area

Using and Arcmap software program, the model was applied to the study area and sensitive areas were obtained (Fig. 2).

\section{DISCUSSION AND CONCLUSION}

The Analytic Hierarchy Process shows the linear model of environmental protection of the province of Bushehr (situated in the south of Iran and on the northern shores of the Persian Gulf) coastal shoreline, according to the following parameters:

Coastal unevenness: coastal habitats; sensitive and rare animal groups; protected rare plants; coastal area's protection record and value of the coastal area for tourism.

This study has evaluated that the most important and priceless environmental parameters for the protection of Bushehr's coastal region are the existence of sensitive habitats, such as mangrove forest, coral reefs and the areas where sea grass, algae and marshland grass are found. Amongst these habitats, coral reefs and mangrove forests (Avicenna Marine Forests) are to be considered as the most important parameters. These are followed in order of importance by the groups of sensitive animal and plants. In the group of existent sensitive animals in the coastal area, sea turtles must be mentioned, specially the areas where they lay eggs, which is a factor of extreme importance in the protection of coastal area. 
Mangrove jungles are to be considered as the most important plant life of the coastal area. The groups of protected animals are of equal importance in the evaluation of protected areas of the Bushehr coastal area. The most important of these is the "Gazelle Dorcas" in the back-shore area, and the "Numenius Arquatain" in the coastal shore area. The coastline's history of protection is also recognized as a sensitivity characteristic. Because of habitat conditions and under water dwelling animal life of the coastal shore, coastal unevenness and land forms make up 4 percent of the importance of Bushehr's coastal protective zone. Amongst the recognized side effects, hydrologic forms, in particular estuaries are considered as a more important protective factor than other coastal genus. Amongst the various coastal genus, cliffs followed by mud flats, play a more important role than other genus do.

The length of Bushehr Province's coastal line is $744.49 \mathrm{kms}$, of which, $70.81 \mathrm{kms}$ surround the islands of Khark, Kharkoo, Shif, Nakhiloo, Omolgorm, Nakhl Nakhoda. And due to the presence of the three protected zones of the coastal area of Bushehr Province, which are: the Marine National Park of Nayband (37.87 kms coastal line), Mond (108.01 kms coastal line) and Hele (27.32 kms coastal line), at present, 23 percent of the Province of Bushehr's coastal line are in contact with the waters of the Persian Gulf's northern shore and are considered as protected areas.

This study emphasizes that the southern coast of the Province of Bushehr, in the townships of Kanghan and Dayr, have a higher potential sensitivity, than the northern coast of the province. However, no other area has been identified that could be incorporated into the network of protection of the coastal "ribbon" of the Province of Bushehr.

The most important recommendation for the management of preserving the ecological values of the Bushehr coastal shore line is increasing the environmental quality of the existing areas.

It is obvious, that by increasing manpower facilities of supervision, guarding protected areas and increasing the quantity of environment inspecting stations, could become examples to imitate.

As far as it can be foreseen in the future, the aforementioned areas cannot achieve the values that this study has identified for them, because of economical development factors.

Study of environmental subjects is highly recommended, in order to be able to comply data, so that future environmental renovations may be carried out.

It is also recommended, that because of intensive oil industry activities being carried out in the coastal area, and in view of the fact, that these activities are the single most polluting factor of the area's environment, environmental related technical "know how", in relation to oil and gas industries up and low stream operations 
be drawn up as a master management plan. It is obvious that drawing up environmental quality standards, especially in regard to the evacuation of effluents into the coastal waters, the quality of the air and sound control can be examples of priority actions.

\section{REFERENCES}

-Danehkar, A. \& H. Madjnonian. (2004). Criterion recommendation for assessment of coastal-marine area for determination of coastal and marine protected area in Iran. Mohitshenasi, 35:9-32

- Danehkar, A. (2002). Sea sensitive areas of Iran and view of development. $5^{\text {th }}$ International Conference on Coasts, Ports and Marine Structures (ICOPMAS), Ramsar, and 14-17 October.

- Davis, T.J. (1994). The Ramsar Convention Manual. A Guid to the convention on wetlands of international imprance especially as water fowl habitat. Ramsar convention Bureau, Gland, Switzerland.

- Evans, M.I. (1994). Important Bird Area in the Middle Est. Birdlife International

IMO/MEPC 46/23., 2001. Guidelines for the identification and design nation of particularly sensitive sea areas. ANNEX 6, Jan.

-IUCN/WCPA. (1999). Guidelines for Marine Protected Areas. Edited \& cordinated by Graeme Kelleher.

-IUCN. (1999). Guidelines for Marine Protected Areas.Edited\&Cordinated by G.R.A.Eme 7 K.Green.

-Kelleher,G. \& R. Kenchington. (1992). Guidelines for Establishing Marine Protected Area. A Marine Conservation \& Development Report, IUCN.

-Kelleher,G. \& R. Kenchington. (1990). Political and Social Dynamics for Establishing Marine Protected Areas. IUCN.

-Kelleher,G. R.Kenchington \& R.Thackeay. (1998). Guidlines for Establishing the National System of Marine Protected Areas. D.O.E., Australia.

- Kiabi, H., Madjnonian, H., Goshtasb.M, H., \& Mansori, J. (2004). Criteria for assessing the conservation status of Iranian wetlands. Mohitshenasi, 33:74-89

Table 1: Influencing Parameters in the sensitivity evaluation of coastal region

\begin{tabular}{|c|c|c|c|c|c|c|}
\hline No & $\begin{array}{c}\text { Main } \\
\text { criteria }\end{array}$ & $\begin{array}{l}\text { Importance } \\
\text { Factor }\end{array}$ & $\begin{array}{c}\text { Secondary Criteria } \\
\text { 1st.Degree } \\
\end{array}$ & $\begin{array}{c}\text { Importance } \\
\text { Factor }\end{array}$ & $\begin{array}{l}\text { Secondary Criteria } \\
\text { 2nd Degree }\end{array}$ & $\begin{array}{l}\text { Importance } \\
\text { Factor }\end{array}$ \\
\hline \multirow{10}{*}{1} & \multirow{10}{*}{$\begin{array}{c}\text { Uneven } \\
\text { Coast }\end{array}$} & \multirow{10}{*}{0.0377} & \multirow{4}{*}{ Hydrologic Form } & \multirow{4}{*}{0.75} & Creeks & 0.081 \\
\hline & & & & & Estuaries & 0.549 \\
\hline & & & & & Gulf & 0.231 \\
\hline & & & & & Wetlands & 0.137 \\
\hline & & & \multirow{6}{*}{ Coastal Genus } & \multirow{6}{*}{0.25} & Cliffs & 0.412 \\
\hline & & & & & Gravel & 0.096 \\
\hline & & & & & Mixed sand \& gravel & 0.055 \\
\hline & & & & & $\begin{array}{l}\text { Sand(Medium } \\
\text { Grained) }\end{array}$ & 0.089 \\
\hline & & & & & Sand( Fine Grained) & 0.104 \\
\hline & & & & & Mud & 0.241 \\
\hline \multirow{5}{*}{2} & \multirow{5}{*}{ Coastal Habitat } & \multirow{5}{*}{0.381} & Mangroves & 0.303 & & \\
\hline & & & Coral Reefs & 0.477 & & \\
\hline & & & Sea - Weeds & 0.118 & & \\
\hline & & & Sea alga & 0.053 & & \\
\hline & & & Marsh grass & 0.46 & & \\
\hline \multirow[t]{5}{*}{3} & \multirow{5}{*}{$\begin{array}{c}\text { Sensitive Animal } \\
\text { Groups }\end{array}$} & \multirow[t]{5}{*}{0.165} & \multirow{2}{*}{ Sea turtles } & \multirow{2}{*}{0.625} & Feeding areas & 0.166 \\
\hline & & & & & Egg Laying areas & 0.833 \\
\hline & & & \multirow{2}{*}{ Aquatic Birds } & \multirow[t]{2}{*}{0.078} & Sea Birds & 0.333 \\
\hline & & & & & Water fowls & 0.666 \\
\hline & & & $\begin{array}{c}\text { Fish } \\
\text { Sea Mammals }\end{array}$ & $\begin{array}{l}0.089 \\
0.206\end{array}$ & Whales & 0.75 \\
\hline
\end{tabular}




\begin{tabular}{|c|c|c|c|c|c|c|}
\hline \multirow{10}{*}{4} & \multirow{10}{*}{ Protected Animals } & \multirow{10}{*}{0.1365} & \multirow{4}{*}{ Protected Mammals } & \multirow{4}{*}{0.666} & Dolphins & 0.25 \\
\hline & & & & & Gazelle (Dorcas) & 0.164 \\
\hline & & & & & Felis Chaus & 0.269 \\
\hline & & & & & Hynex Caracal & 0.117 \\
\hline & & & \multirow{6}{*}{ Protected Birds } & \multirow{6}{*}{0.333} & Chlamydotis Undulate & 0.31 \\
\hline & & & & & Numenius Tenuirostris & 0.334 \\
\hline & & & & & Grus Arus & 0.274 \\
\hline & & & & & Falconidae Family & 0.085 \\
\hline & & & & & Anatidae Family & 0.087 \\
\hline & & & & & Phesianidae Family & 0.087 \\
\hline \multirow{3}{*}{5} & \multirow{3}{*}{ Protected Plants } & \multirow{3}{*}{0.1507} & Avicenna & 0.745 & & \\
\hline & & & Tecomella Undulo & 0.156 & & \\
\hline & & & Ficus Reliqiosa & 0.098 & & \\
\hline \multirow{3}{*}{6} & \multirow{3}{*}{ Tourist centers } & \multirow{3}{*}{0.021} & $\begin{array}{c}\text { Historical } \\
\text { centers/points }\end{array}$ & 0.582 & & \\
\hline & & & Cultural centers & 0.384 & & \\
\hline & & & Coastal promenades & 0.069 & & \\
\hline \multirow{3}{*}{7} & \multirow{3}{*}{ Protected Areas } & \multirow{3}{*}{0.1081} & Marine national park & 0.7 & & \\
\hline & & & Protected areas & 0.243 & & \\
\hline & & & Wild life refuge & 0.056 & & \\
\hline TOTAL & 7 & & 22 & & 25 & \\
\hline
\end{tabular}

Michel, J. (1999).The Archetypical Environmental Sensitivity Index. Research Planning, Inc.NOAAs Ocean Service.

Saaty, T.L. (1996). Analytical Network Processes, USA: RWS Publication.

Saaty, T.L. (1988). Hierarchy and Priority in Saaty, T.L. and Alexander J.M., the Thinking with Models: Mathematical Models in Physical and Social Sciences, Oxford: Bergamo Press, pp. 148-155

Saaty, T.L. (1990). Decision Making for Leaders, USA: RWS Publication.

Saaty, T.L. (1980). The Analytical Hierarchy Process, Planning, Priority, Resource Allocation, and USA: RWS Publication.

Salm,R.V. \& A.Price. (1995). Selection of Marine Protected Areas: Principles of Techniques for Management. Edited by Susan Gubby. Chapman and Hall, London.

Salm, R.V. \& Clark, J.R. (1984). Marine and Coastal Protected Areas: A guide for planners and managers. IUCN, Gland, Switzerland. 
Evaluation of the Ecological Sensitivity ...

NOURI, J; DANEHKAR, A; SHARIFIPOUR, $R$ 